\title{
Декларация ООН о правах коренных народов как важный шаг на пути к восстановлению справедливости
}

\section{Гарипов Р.Ш.*}

В июне 2006 года Совет по правам человека $\mathrm{OOH}$ на своей первой сессии большинством голосов принял Декларацию о правах коренных народов и представил ее на обсуждение Генеральной Ассамблее $\mathrm{OOH}$.

В ходе дискуссий ряд государств, таких как США, Канада, Австралия и Новая Зеландия, выступали с резкой критикой текста Декларации, делая упор на то, что документ дает слишком широкое толкование права коренных народов на самоопределение (ст. 3, 4), которое может представлять реальную угрозу территориальной целостности государств. Эти страны также были недовольны тем, каким образом Декларация закрепляет права коренных народов на земли, территории и природные ресурсы, которыми они традиционно владели (ст. 26). Странами - сторонниками принятия Декларации был предложен компромиссный текст резолюции, включающий в себя упоминание о необходимости учета территориальной целостности, независимости и политического единства государств (ст. 46). В декабре 2006 года Генеральной Ассамблеей было принято решение о продолжении консультаций и поиске формулировок, которые бы смогли удовлетворить все заинтересованные стороны.

И вот в сентябре 2007 года Генеральная Ассамблея ООН приняла Декларацию о правах коренных народов. За ее принятие проголосовали 143 члена ООН, 11 воздержались, и 4 государства высказались против: это США, Канада, Австралия и Новая Зеландия. Россия находится в числе воздержавшихся.

\footnotetext{
* Гарипов Руслан Шавкатович - зав. кафедрой государственно-правовых дисциплин Татарского государственного гуманитарно-педагогического университета (г. Казань). В период с марта по август 2007 г. проводил исследование по проблемам защиты прав коренных народов в рамках программы Фулбрайт в Институте Кеннана Международного центра исследований им. Вудро Вилсона, г. Вашингтон. В мае 2007 г. участвовал в качестве наблюдателя в шестой сессии Постоянного Форума ООН по вопросам коренных народов, г. Нью-Йорк.
} 
Принятие Декларации стало важным и долгожданным событием для коренных народов всего мира. Как отмечает в своем заявлении Директор Центра правовых ресурсов коренных малочисленных народов Севера, Сибири и Дальнего Востока Михаил Тодышев: «В последние дни 61-й сессии Генеральной Ассамблеи ООН большинством голосов был принят этот важнейший для нас документ в качестве общепризнанной нормы международного права. Впереди нам предстоит большая работа по применению Декларации в России, совершенствованию законодательства на федеральном и региональном уровнях, а также процесс разработки Конвенции о правах коренных народов» ${ }^{1}$.

По данным ООН, в мире к коренным народам относятся свыше 300 млн человек более чем в 70 странах, и многие из них находятся на грани исчезновения ${ }^{2}$. Активисты движения в защиту прав этих народов отмечают, что они, как никогда раньше, подвергаются мощному давлению со стороны строителей, фермеров, деревоперерабатывающих и горнодобывающих компаний. Международному сообществу необходимо обращать внимание на проблемы коренных народов и делать все возможное для сохранения их самобытности.

Являясь наследниками уникальных культур и обладая отличным от других народов социальным, экономическим и политическим укладом жизни, они стараются сохранить свой образ жизни в обществе, где доминирует совершенно иная культура. Коренные народы находятся в числе наиболее уязвимых слоев населения. На протяжении истории их права нарушались самым грубым образом, их истребляли, отнимали земли и переселяли в непригодные для жизни территории. Ситуация стала меняться только лишь в XX веке, международное сообщество опомнилось, и в ряде государств стали идти на уступки представителям коренных народов. Так, например, в Соединенных Штатах Америки индейцы были признаны в качестве граждан США только в 1924 году. Сейчас времена изменились, и международное право признает право

1 Cм.: http://www.raiponlaw.org/news/arhiv_june_september_2007/dekl_un_13092007. $\mathrm{htm}$

2 Что касается Российской Федерации, у нас используется термин «коренные малочисленные народы». Это понятие включает в себя 45 народностей, проживающих на территориях традиционного расселения своих предков, сохраняющих традиционные образ жизни, хозяйствование и промыслы, насчитывающих в Российской Федерации менее 50 тысяч человек и осознающих себя самостоятельными этническими общностями. См.: Федеральный закон от 30.04.1999 г. № 82-Ф3 «О гарантиях прав коренных малочисленных народов Российской Федерации». 
коренных народов на восстановление исторической справедливости и защиту их традиционного образа жизни. В 1994 году Генеральной Ассамблеей было объявлено десятилетие защиты прав коренных народов. В 2005 году ООН вновь объявило десятилетие, посвященное защите прав коренных народов, целью которого является дальнейшее сотрудничество международного сообщества в решении самых различных задач в области культуры, образования, медицины, прав человека, экологии, а также социального и экономического развития коренных народов.

Начало борьбе коренных народов за свои права на международном уровне было положено еще в 1924 году, когда вождь племени Кайюга конфедерации ирокезов по имени Дескахех отправился в Женеву с намерением выступить в Лиге Наций. Ему не дали возможности выступить, но он все таки сумел обратить внимание международной общественности на проблемы своего народа и стал одним из лидеров борьбы за права североамериканских индейцев, продолжающейся и по сегодняшний день. ${ }^{3}$ Поэтому принятие Декларации о правах коренных народов стало важным шагом на пути к восстановлению исторической справедливости и признанию на международном уровне прав коренных народов.

В Декларации говорится, что коренные народы равны со всеми другими народами и признается право всех народов отличаться друг от друга. Все народы вносят вклад в многообразие и богатство различных культур и цивилизаций и являются общим наследием человечества, любая дискриминация является несправедливой, научно несостоятельной и юридически недействительной. В документе выражается обеспокоенность тем, что коренные народы стали жертвами исторических несправедливостей вследствие колонизации их земель, и признается необходимость уважать их политические, экономические и социальные права, а также культуру, традиции и собственную философию.

3 В США североамериканские индейцы до сих пор ведут активную борьбу за соблюдение их прав и улучшение уровня жизни. Так, например, знаменательно одно из последних заявлений вождей сиу, сделанное в середине декабря 2007 г. о расторжении всех подписанных ранее с правительством США договоров и выходе из состава страны с образованием своего собственного независимого государства. Были разосланы соответствующие уведомления в дипломатические представительства ряда государств с просьбой признать новое государство, на территории которого уже ведется выдача своих собственных паспортов и водительских удостоверений. Особенно интересен тот факт, что данное заявление было сделано в то время, когда США на международном уровне призывают признать независимость Косово, ссылаясь на право албанского народа на самоопределение. 
Высказывается убеждение в необходимости осуществления коренными народами контроля над их землями, территориями и ресурсами, что будет способствовать их устойчивому развитию и удовлетворению потребностей. Упоминается о демилитаризации земель и территорий коренных народов, а также о заботе и сохранении окружающей среды. Особо отмечается в Декларации право народов на самоопределение, в силу которого они свободно устанавливают свой политический статус и осуществляют экономическое, социальное и культурное развитие. Декларация, как говорится в документе, провозглашается в качестве эталона, которому надлежит следовать в духе партнерства и взаимного уважения.

Документ состоит из 46 статей и предусматривает защиту самого широкого круга прав коренных народов, в числе которых особо следует отметить право на самоопределение и право на землю и природные ресурсы. Именно по ним и разворачивались основные дискуссии в процессе принятия Декларации. Так, например, на шестой сессии Постоянного Форума ООН по вопросам коренных народов в мае 2007 года основной темой обсуждения явилась Декларация, и в частности вопросы, связанные с правами коренных народов на их исконные земли и право на самоопределение 4 .

Статьи 3 и 4 Декларации гласят: «Коренные народы имеют право на самоопределение. В силу этого права они свободно устанавливают свой политический статус и свободно осуществляют свое экономическое, социальное и культурное развитие. Коренные народы при осуществлении их права на самоопределение имеют право на автономию или самоуправление в вопросах, относящихся к их внутренним и местным делам, а также путям и средствам финансирования их автономных функций» ${ }^{5}$.

Принцип равноправия и самоопределения народов принадлежит к числу основных принципов международного права в соответствии с Уставом ООН, составляя, таким образом, одно из важнейших начал современного международного права и международного правопорядка в целом. Предотвращение и устранение угрозы миру, улаживание

4 См. более подробно: Гарипов Р.Ш. Шестая сессия Постоянного Форума ООН по вопросам коренных народов // Казанский журнал международного права. Казань, 2007. № 1. С. 50.

5 См.: Декларация о правах коренных народов // http:/documents-dds-ny.un.org/doc/ UNDOC/LTD/N07/498/32/pdf/N0749832.pdf?OpenElement. 
международных споров, которые могут привести к нарушению мира, нередко связано с осуществлением данного принципа. Однако самоопределение народа не должно быть самоцелью, а должно служить средством защиты прав человека ${ }^{6}$. В ст. 55 Устава ООН процесс самоопределения народов причислен к оптимальным условиям стабильности и благополучия, всеобщего уважения и соблюдения прав человека и основных свобод для всех, без какой-либо дискриминации.

Самоопределяться народ может и в пределах государства, не нанося при этом ущерба ни своей самобытности, ни процессам своего культурного, социального, экономического и исторического развития, ни территориальной целостности государства своего проживания. В связи с этим уместно привести точку зрения профессора И.П. Блищенко, который отмечал по этому поводу следующее: «Под самоопределением нельзя понимать только политическую независимость. В подавляющем большинстве случаев политическая независимость не решает проблемы, стоящей перед народом или нацией, то есть не решает проблемы развития данного народа или нации» ${ }^{7}$. Поэтому современная тенденция развития права народов на самоопределение такова, что оно осуществляется в границах государства, в состав которого входит народ, в формах, предусмотренных внутригосударственным правом, например национально-культурных, территориальных автономий, республик, резерваций и т.д., то есть так называемое «внутреннее самоопределение» ${ }^{8}$.

Декларация также закрепляет за представителями коренных народов и такие неотъемлемые права, как право на жизнь, физическую и психическую неприкосновенность, личную безопасность; право на жизнь в условиях свободы, мира и безопасности в качестве самобытных народов; запрет на любые акты геноцида или насилия в отношении коренных народов. Статья 8 документа запрещает принудительную ассимиляцию или любое другое воздействие в целях уничтожения культуры, чем в общем-то и занималось американское правительство на протяжении долгого времени в отношении индейского населения. Проводимая ими политика принудительной ассимиляции не привела

6 См.: Балаян Н.А. Новые подходы к соотношению принципов территориальной целостности и равноправия и самоопределения народов // Российское право в Интернете. 2005. № 3. / http://www.rpi.msal.ru/prints/200503internlaw1.html.

7 См.: Блищенко И.П. Автономия и международное право // Московский журнал международного права. № 1. 1998. С. 4.

8 См.: Романов В.А. Принцип самоопределения и территориальная целостность государств // Дипломатический вестник. 2000. № 9. С. 5. 
к особым успехам, а лишь ожесточила позицию индейцев по отношению к правительству США, после чего последовала политика изоляции и полного игнорирования требований коренных народов.

Отныне запрещается принудительное удаление коренных народов со своих земель или территорий. Никакое перемещение не осуществляется без их свободного, предварительного и осознанного согласия. Если же перемещение и производится, то только после заключения соответствующего соглашения с обязательной выплатой компенсации и возможностью возвращения. Таким образом, освоение новых земель, добыча ресурсов и полезных ископаемых теперь не являются основанием для депортации целых народов с их земель или «добровольного» перемещения 9 .

В Декларации уделяется внимание защите культурных и религиозных прав коренных народов. Предусматривается возможность реституции в отношении их культурной, интеллектуальной, религиозной и культовой собственности, отчужденной без их согласия. Дается право создавать свои собственные учебные заведения, обеспечивающие образование на их родном языке и с учетом культурных традиций. Декларируется возможность создавать свои собственные средства массовой информации.

Внимание уделяется также соблюдению трудовых прав представителей коренных народов. Запрещается любая дискриминация в их отношении, что касается условий труда, занятости и заработной платы. Социально-экономические условия жизни должны постоянно улучшаться и в сфере здравоохранения, и в области обеспечения жильем, социальной помощи и т.д.

Декларация призывает правительства государств, на территории которых проживают коренные народы, предоставить им больший контроль над землей и природными ресурсами, а также вернуть им ранее конфискованные земли или выплатить компенсацию. Именно по этим вопросам и развернулись наиболее жаркие дискуссии. Так, Австралия заявила, что не допустит, чтобы традиционные законы аборигенов были важнее национальных. «У всех австралийцев должен быть только один

9 Так, например, в США, в XIX веке под влиянием угроз и обмана ряд племен подписали заведомо неравноправные договоры и были перемещены со своих земель. Известная «Дорога слез», когда племя чероки было отправлено на запад в Оклахому со своих исконных территорий с целью освобождения плодородных земель под заселение американскими гражданами. Или перемещение индейцев сиу с их священной земли «Черные холмы», где было обнаружено золото. 
закон, и мы не должны закреплять в законодательном порядке вещи, которые неприемлемы в современном мире», - заявил австралийский министр по делам туземных народов Мэл Броу ${ }^{10}$.

Статьи 26, 27 и 28 Декларации стали, по сути, ключевыми положениями документа, закрепляющими за коренными народами беспрецедентные права и огромные ресурсы. «Государства с должным признанием законов, традиций, обычаев и систем землевладения коренных народов устанавливают и осуществляют совместно с соответствующими коренными народами справедливый, независимый, беспристрастный, открытый и транспарентный процесс признания и юридического подтверждения прав коренных народов в отношении их земель, территорий и ресурсов, включая те, которыми они традиционно владели или которые они иным образом занимали или использовали. Коренные народы имеют право участвовать в этом процессе», - так гласит статья 27 Декларации ${ }^{11}$.

Канадское правительство заявило, что поддерживает «дух» Декларации, но не саму Декларацию, поскольку некоторые ее положения несовместимы с конституцией страны. «Кроме того, Декларация не признает необходимость сочетать права коренных народов Канады на землю и ресурсы с правами других людей», - говорится в совместном заявлении канадского МИДа и Министерства по делам индейцев. Население Канады составляет 32,7 млн человек, из них 1,3 млн - представители коренных народов ${ }^{12}$. При этом канадские иннуиты борются за сохранение традиционного образа жизни, в то время как правительство страны дает разрешение на разработку природных месторождений и строительство гидроэлектростанций и дорог на их территории.

Российская Федерация также находится в числе несогласных с рядом предписаний Декларации, в частности по вопросам земли и ресурсов, и заявила, что эти положения неприемлемы и для России.

Согласно Декларации, коренные народы самостоятельно определяют приоритеты и стратегию освоения своих земель, территорий и ресурсов. Государства обязаны консультироваться и сотрудничать с коренными народами при утверждении любого проекта, затрагивающего их интересы, особенно в связи с освоением, использованием

10 См.: http://www.korrespondent.net/main/print/207267.

11 См.: Декларация о правах коренных народов // http://documents-dds-ny.un.org/doc/ UNDOC/LTD/N07/498/32/pdf/N0749832.pdf?OpenElement.

12 CM.: http://www.korrespondent.net/main/print/207267. 
или разработкой полезных ископаемых, водных и других ресурсов. Государства должны обеспечивать эффективные механизмы возмещения в связи с такой деятельностью и принимать все необходимые меры для устранения неблагоприятных последствий и вреда окружающей среде, экономике, культуре и т.д. ${ }^{13}$. Запрещаются также любая военная деятельность на землях и территориях коренных народов и хранение или удаление опасных материалов.

Достаточно востребованной является норма Декларации (ст. 36), предписывающая сопредельным государствам поддерживать и развивать контакты коренных народов, разделенных международными границами. В мире достаточно примеров, когда один и тот же народ оказывается в разных государствах. Так, например, племя могавков, исторически обитавшее в районе Великих озер, оказалось разделенным и имеет резервации на территории США и Канады. Государствами был установлен специально для них безвизовый режим пересечения границы в целях облегчения контактов членов племени.

В заключение документа отмечается, что государства должны принимать меры, в том числе и законодательные, для достижения целей настоящей Декларации. Органы и специализированные учреждения $\mathrm{OOH}$, а также другие межправительственные организации должны содействовать соблюдению и применению положений Декларации. Признанные в документе права коренных народов представляют собой минимальные стандарты для обеспечения их выживания, уважения достоинства и благополучия.

Таким образом, Декларация стала важным шагом на пути к восстановлению исторической справедливости и достойным завершением длительных переговоров по вопросам коренных народов мира. Она на международном уровне закрепила право коренных народов осуществлять контроль над собственными землями, территориями и ресурсами, дала возможность им самим строить свою общественную жизнь, сохранять культуру и традиции и развиваться в соответствии с их стремлениями и потребностями.

13 Так, например, добыча урана правительством США на территории самой большой резервации в штате Аризона нанесла непоправимый вред окружающей среде и экологии региона и унесла жизни многих жителей из числа племени навахо, привлекаемых к работам в шахтах. 


\section{The UN Declaration on the Rights of Indigenous Peoples as an Important Step towards Justice Restoration (Summary)}

\section{Ruslan Sh. Garipov*}

This article examines the provisions of the Declaration on the Rights of Indigenous Peoples which was adopted by the UN Human Rights Council on June 29, 2006 and was ratified by the UN General Assembly on September 13, 2007.

This document proclaims cultural, religious, educational and other rights of indigenous peoples. The Declaration allows the indigenous people to participate in the political and social life of their country's community. It fixes the right of self-determination, which means that indigenous people can establish their own political status and economic, social and cultural development. They have the right of autonomy and self-government in their domestic issues.

The document states that indigenous people should be protected against violent assimilation and violent deportation from their lands and also from any other discrimination. Indigenous people can keep their traditions, language; they should have access to their sacred places. Indigenous people can create their own media services in their native language; they can keep their own traditional medicine and so on.

But the main part of this document is the proclamation of indigenous people's land rights. Article 26 of the Declaration allows indigenous people to hold their native land and its natural recourses.

After the analysis given in this article the author arrives to the following conclusion: the Declaration as a result of more than two decades of negotiation emphasizes that indigenous peoples' control over their lands, territories and resources will enable them to maintain and strengthen their institutions, cultures and traditions and to promote their development in accordance with their aspirations and needs.

\footnotetext{
* Ruslan Sh. Garipov - Doctor of Laws, Chair of the Department of state and law disciplines of the Tatar State Humanitarian and Pedagogical University (Kazan). From March to September, 2007 was Fulbright-Kennan Scholar at Woodrow Wilson International Center for Scholars, Washington, DC, USA. In May 2007 participated as observer in the Sixth Session of the United Nations Permanent Forum on Indigenous Issues, New York, USA.
} 